\title{
Description of new cicada species associated with the coffee plant and an identification key for the species of Fidicinoides (Hemiptera: Cicadidae) from Brazil
}

\author{
RODRIGO SOUZA SANTOS ${ }^{1}$, NILZA MARIA MARTINELLI ${ }^{2}$, DOUGLAS HENRIQUE BOTTURA \\ MACCAGNAN $^{2}$, ALLEN F. SANBORN ${ }^{3,5} \&$ RENATO RIBEIRO $^{4}$ \\ ${ }^{1}$ Pós-doutorando da EMBRAPA Amapá - Centro de Pesquisa Agroflorestal do Amapá (CPAFAP). Rodovia Juscelino Kubitschek, Km \\ 5, no 2.600, CEP: 68903-419, CP. 10, Macapá,AP,Brasil.E-mail: santos_rss@hotmail.com \\ ${ }^{2}$ Faculdade de Ciências Agrárias e Veterinárias (FCAV/UNESP), Via de Acesso Prof. Paulo Donato Castellane s/n, CEP: 14884-900, \\ Jaboticabal, SP, Brasil. E-mail: nilza@fcav.unesp.br \\ ${ }^{3}$ Department of Biology, Barry University, 11300 NE Second Avenue, Miami Shores, FL 33161-6695, USA. \\ E-mail: asanborn@mail.barry.edu \\ ${ }^{4}$ CIMOAGRO - Comércio e Representação Agropecuária S/C Ltda., Avenida São Sebastião, nº. 130, Vila Cantizane, CEP: 18800-000, \\ Pirajú, SP, Brasil. E-mail: renato.ribeiro@cimoagro.com.br \\ ${ }^{5}$ Corresponding author.E-mail: asanborn@mail.barry.edu
}

\begin{abstract}
The genus Fidicinoides Boulard \& Martinelli is characterized by its partially exposed timbal, not totally covered by the meta-scutellar plate as occurs in Fidicina Amyot \& Serville, and has an extensive geographic distribution in Central and South America. In this work a new species for the genus is described. Fidicinoides sarutaiensis Santos, Martinelli \& Maccagnan sp. n. is a medium-sized cicada, with the collected and studied specimens associated with coffee (Coffee arabica L.), in the municipality of Sarutaiá, in the southeast region of São Paulo state. The species $F$. glauca (Goding, 1925 ) and F. viridifemur (Walker, 1850) are transferred to Dorisiana. An identification key for the Fidicinoides species of Brazil is also proposed.
\end{abstract}

Key words: Homoptera, Coffea arabica, Fidicinini, morphology, taxonomy

\section{Resumo}

O gênero Fidicinoides Boulard e Martinelli é caracterizado por apresentar o tímbalo parcialmente exposto, não recoberto totalmente pela placa metaescutelar como ocorre em Fidicina Amyot e Serville, sendo de ampla distribuição geográfica nas Américas Central e do Sul. Neste trabalho é descrita uma nova espécie para o gênero. Fidicinoides sarutaiensis Santos, Martinelli e Maccagnan sp. n. é uma cigarra de médio porte, sendo os espécimes estudados, coletados associados ao cafeeiro (Coffee arabica L.), no município de Sarutaiá, região sudoeste do Estado de São Paulo. As espécies $F$. glauca (Goding, 1925) e F. viridifemur (Walker, 1850) são transferidas para Dorisiana. Também é proposta uma chave de identificação para espécies de Fidicinoides do país.

Palavras-chave: Cigarra, Coffea arabica, Fidicinini, morfologia, taxonomia

\section{Introduction}

According to Moulds' (2005) classification, the superfamily Cicadoidea includes two extant families: Tettigarctidae and Cicadidae. The tribe Fidicinini of the family Cicadidae is represented by several Neotropical genera. An important morphological characteristic for the diagnosis of the genera of this tribe is the more or less pronounced manifestation of the orifice of the stridulatory organ (Distant 1906). 